\title{
Tingkat Kecerdasan Mahasiswa Ditinjau dari Perbedaan Fakultas di Lingkungan UIN Malang
}

\author{
Retno Mangestuti \\ Dosen Fakultas Psikologi Universitas Islam Negeri (UIN) Malang
}

\begin{abstract}
The aims of this research is to study the difference of Intelligent Quotient (IQ), Emotional Intelligence (EI), Spiritual intelligence among faculty in UIN Malang.

The subjects in this research were 304 student of Islamic State University in Malang, using proportional random sampling technique, with the result that representative and balance each faculty. The instrument used in this research are IQ test and psychologis scale. Psychologis scale are spiritual intelligence scale, emotional intelligence scale, and agresivity scale. The data were analyzed using analysis of variance with SPSS version 10.0 for windows.

The research result show: that there's differences among faculty in UIN Malang at Intelligent Quotient but there's no differences among faculty in UIN Malang at Emotional Intelligence and Spiritual Intelligence.
\end{abstract}

Key word: intelligent quotient, spiritual intelligence, emotional intelligence.

\section{A. Latar Belakang Masalah}

Allah telah menciptakan manusia sebagai makhluk yang sangat sempurna, dengan dibekali berbagai potensi, seperti yang tercantum dalam surat At Tin ayat 3: "dan sungguh telah kami ciptakan manusia dalam sebaikbaiknya bentuk". Salah satu bentuk kelebihan manusia dibanding makhluk lainnya adalah adanya kemampuan manusia untuk bersikap dan berperilaku secara inteligen.

Inteligensi merupakan salah satu potensi individu dalam bentuk ukuran kapasitas tertentu dalam menerima dan merespon stimulus dari luar yang kemudian dikelola dengan menggunakan akal untuk menentukan bentuk-bentuk reaksi dalam perilakunya. Inteligensi merupakan kapasitas 
bawaan yang diturunkan secara genetik dari orangtuanya. Masyarakat awam, mengenal inteligensi sebagai istilah yang menggambarkan kecerdasan, kepintaran, ataupun kemampuan untuk memecahkan masalah yang dihadapi, yang selanjutnya lebih dikenal dengan istilah kecerdasan intelektual.

Setidaknya saat ini dikenal adanya beberapa jenis kecerdasan, diantaranya adalah jenis kecerdasan intelektual yang biasa dikenal dengan istilah intelligence quotient (IQ) yaitu ukuran kecerdasan seseorang dalam menyelesaikan masalah secara tepat.

Pada tahun 1995, Daniel Goleman mempopulerkan suatu konsep baru dalam bidang psikologi yang disebut dengan Emotional Intelligence. Menurut Goleman (1996) kecerdasan intelektual (IQ) bila tidak disertai dengan pengolahan emosi yang baik tidak akan menghasilkan seseorang sukses dalam hidupnya. Peranan IQ hanyalah sekitar $20 \%$ untuk menopang kesuksesan hidup seseorang, sedangkan $80 \%$ lainnya ditentukan oleh faktor yang lain. Selanjutnya ia mengatakan bahwa pentingnya pengelolaan emosi bagi manusia dalam pengambilan keputusan bertindak adalah sama pentingnya, bahkan seringkali lebih penting daripada nalar, karena menurutnya, kecerdasan intelektual tidak berarti apa-apa bila emosiyang berkuasa.

Pada pertengahan tahun 2000, dunia psikologi dikejutkan kembali oleh adanya penemuan baru yang dikemukakan oleh Danah Zohar dan Ian Marshall tentang kecerdasan manusia yang berhubungan dengan spiritual, yang dikenal dengan sebutan kecerdasan spiritual. Selanjutnya Zohar \& Marshal (2000) mengatakan bahwa kecerdasan spiritual merupakan kecerdasan untuk menghadapi dan memecahkan persoalan makna dan nilai dalam kehidupan.

Menurut Ginanjar (2003) ketiga bentuk kecerdasan tersebut diatas sangat penting dan harus dikembangkan dalam kehidupan seseorang. Hal ini disebabkan karena kecerdasan intelektual diperlukan untuk mengatasi masalah-masalah yang berhubungan dengan aspek kognitif, kecerdasan emosional diperlukan untuk mengatasi masalah afektif, dan kecerdasan spiritual diperlukan untuk mengatasi masalah kebermaknaan dalam menjalani kehidupan.

Dalam konteks penelitian ini, istilah kecerdasan intelektual biasa disebut dengan IQ, kecerdasan emosional dikenaldengan EI, dan kecerdasan 
spiritual dikenaldengan istilah SI. Penulis lebih sepakat dengan penggunaan EI dan SI bukan istilah EQ dan SQ. Hal ini didasarkan pada anggapan bahwa emosi dan spiritual adalah dua konstruk psikologis yang bersifat dinamis yang perkembangannya berbeda dengan konsep kognitif. Perkembangan kognitiflebih bersifat progresif sampai pada usia tertentu sehingga bisa diukur dengan cara membagi usia mental (Mental Age) oleh usia kronologis (Cronological Age) yang kemudian dikali 100. Hasil perhitungan inilah yang kemudian disebut dengan istilah Quotient, sedangkan emosi dan spiritual perkembangannya bersifat dinamis, karena itu maka yang diukur dalam kecerdasan emosional dan spiritual terletak pada kualitas kemampuannya yang dalam hal ini dikenal dengan istilah Intelligence.

Dalam perkembangan pendidikan dewasa ini, memang seyogyanya mengadopsi ketiga kecerdasan tersebut (yakni Intelektual, emosional dan spiritual). Demikian pula yang telah dilakukan Universitas Islam Negeri (UIN) Malang, dengan berlandaskan Ulul Albab, berusaha mencetak insan yang tidak hanya berilmu tetapi juga berakhlak mulia. Akan tetapi satu hal yang tidak bisa dipungkiri bahwa UIN Malang adalah perguruan tinggi yang terdiri dari enam fakultas yaitu Fakultas Tarbiyah, Syariah, Humaniora dan Budaya, Psikologi, Ekonomi serta Sains dan Teknologi. Tiap-tiap Fakultas yang ada di UIN Malang ini pada dasarnya memiliki karakteristik, dan kemampuan mahasiswa yang berbeda-beda, baik itu karena faktor genetik (bawaan) maupun faktor lingkungan. Faktor lingkungan disini, bisa berupa lingkungan dimana dia tinggal maupun lingkungan akademis dimana dia belajar.

Berdasarkan uraian diatas maka penulis tertarik untuk meneliti bagaimana perbedaan kecerdasan pada mahasiswa di enam fakultas yang ada di lingkungan Universitas Islam Negeri Malang.

\section{B. Tujuan dan Manfaat Penelitian}

Sesuai dengan rumusan masalah yang telah dikemukakan diatas, maka tujuan yang ingin dicapai dalam penelitian ini adalah untuk mendapatkan data tentang perbedaan tingkat kecerdasan pada enam Fakultas di UIN malang. Hasil penelitian ini menjadi penting mengingat sampai saat ini 
penelitian yang membandingkan tiga jenis kecerdasan pada mahasiswa di enam Fakultas UIN Malang belum pernah dilakukan.

\section{Kajian Pustaka}

\section{Kecerdasan Intelektual}

Masyarakat awam, mengenal inteligensi sebagai istilah yang menggambarkan kecerdasan, kepintaran, ataupun kemampuan untuk memecahkan masalah yang dihadapi. Gambaran anak yang berinteligensi tinggi adalah seorang anak yang pintar yang selalu naik kelas dengan nilai baik. Bahkan, gambaran tersebut meluas pada citra fisik seperti ganteng, berpakaian bersih, matanya bersinar dan lain sebagainya.

Pandangan awam seperti yang digambarkan di atas, walaupun tidak memberikan arti yang jelas tentang inteligensi namun pada umumnya tidak berbeda jauh dari makna inteligensi sebagaimana yang dimaksud oleh para ahli. Apapun definisinya, makna inteligensi memang mendeskripsikan suatu kepintaran dan kebodohan.

Dalam memahami hakekat inteligensi, Maloney dan Ward (1976), mengemukakan adanya empat pendekatan yang bisa diajukan, yaitu: Pendekatan teori belajar. Inti pendekatan teori ini terletak pada pemahaman mengenai hukum-hukum dan prinsip umum yang digunakan oleh individu untuk memperoleh bentuk-bentuk perilaku baru. Oleh karena itu, dalam pendekatan ini para ahli lebih memusatkan perhatiannya pada perilaku yang tampak dan bukan pada pengertian mengenai konsep mental dari inteligensi itu sendiri.

1. Pendekatan teori belajar. Inti pendekatan teori ini terletak pada pemahaman mengenai hukum-hukum dan prinsip umum yang digunakan oleh individu untuk memperoleh bentuk-bentuk perilaku baru.

2. Pendekatan Neurobiologis. Pendekatan ini beranggapan bahwa inteligensi memiliki dasar anatomis dan biologis, sehingga bisa disimpulkan bahwa perilaku inteligen dapat ditelusuri pada dasar-dasar neuro-anatomis dan proses neurofisiologisnya. 
3. Pendekatan Psikometris. Pendekatan ini beranggapan bahwa inteligensi merupakan suatu konstruk atau sifat psikologis yang berbeda-beda kadarnya pada setiap orang. Namun dikarenakan para ahli psikometri biasanya lebih tertarik pada masalah pengukuran psikologis, maka mereka lebih memperhatikan pada cara praktis untuk melakukan klasifikasi dan prediksi berdasarkan hasil pengukuran inteligensi daripada meneliti hakikat inteligensi itu sendiri.

4. Pendekatan Teori Perkembangan. Inti dari pendekatan ini terletak pada perhatiannya terhadap perkembangan inteligensi secara kualitatif dalam kaitannya dengan tahap-tahap perkembangan biologis individu.

Menurut Groth-Marnat (dalam Azwar, 1996), dua pendekatan pertama sangat menarik bila dipandang dari perspektif teoritis, sedangkan dua pendekatan terakhir lebih mempunyai pengaruh pada segi praktis dan lebih banyak dipelajari serta diteliti. Dengan demikian maka penelitian ini menggunakan pendekatan psikometris karena bertujuan untuk mengukur inteligensi dengan ukuran-ukuran tertentu.

Dalam hal pengukuran, para ahli psikologi telah banyak yang berusaha mengadakan pengukuran intelegensi dengan maksud mendapatkan gambaran yang seobyektif mungkin tentang intelegensi individu, melalui pengembangan tes intelegensi. Tes-tes tersebut merupakan instrumen yang diharapkan dapat memberikan informasi tentang kualitas inteligensi (kapasitas intelektual) dengan memakai ukuran kuantitatif. Di antara para ahli psikologi sekaligus sebagai perintis penyusunan tes intelegensi adalah Binet dan Weschler.

Alfred Binet adalah seorang ahli psikologi Prancis. Pada tahun 1905, mulai menyusun tes intelegensi yang dibantu oleh Simon, sehingga skala tes yang dihasilkan sering disebut Skala Binet-Simon. Satuan taraf intelegensi dinyatakan dengan IQ (Intelligence Quotient) yaitu sebagai perbandingan antara umur mental atau mental age (MA) dengan umur kalender atau Chronological Age (CA) dan dikalikan dengan 100 atau

$$
\mathrm{IQ}=\frac{\mathrm{MA}}{\mathrm{CA}} \times 100
$$


Pada tahun 1936 Wechsler mengembangkan tes intelegensi yang relatiflebih baik daripada tes Binet. Tes yang dikembangkan oleh Wechsler itu dapat dipergunakan untuk mengukur inteligensi orang dewasa yang mempunyai rentang sampai umur 64 tahun.

Beberapa tes intelegensi yang dapat digolongkan ke dalam kelompok tes yang bebas pengaruh kebudayaan antara lain adalah Standart Progressive Matrices yang dikembangkan oleh Raven.

Hasil suatu tes inteligensi dapat diinterpretasikan dengan cara membandingkan dengan diri sendiri atau dengan orang lain. Namun yang paling umum, interpretasi hasil suatu tes psikologi biasanya dilakukan dengan membandingkan individu dengan hasil tes individu lain dalam kelompok usianya.

\section{Kecerdasan Emosional}

Emosi adalah perasaan tertentu yang bergejolak dan dialami seseorang serta berpengaruh terhadap kehidupan. Karena itu orang tidak akan pernah dapat lepas dari emosi. Penelitian Martani (1996) membuktikan bahwa emosi-emosi tertentu dapat ditentukan melalui rangsang suara atau gambar. Meskipun dalam hal ini unsur biologis memainkan peran tetapi pengalaman kehidupan serta budaya akan mempengaruhi ekspresinya. Oleh karena itu pengelolaan emosi sangat dimungkinkan, agar kekuatan yang terkandung dalam emosi dapat dimanfaatkan secara positif. Selanjutnya ia mengatakan bahwa, orang yang sehat biasanya mampu mengenal emosi yang dialaminya dan dapat mengekspresikan sesuai dengan aturan yang berlaku di lingkungannya.

Istilah Emotional Intelligence yang dalam bahasa Indonesia diterjemahkan dengan Kecerdasan Emosional, pertama kali diperkenalkan oleh Peter Salovey dari Harvard University dan John Mayor dari University of New Hampshire pada tahun 1990, Kedua tokoh diatas banyak diilhami oleh gagasan dari Gardner yang mengemukakan konsep multiple intelligence, kemudian istilah emotional intelligence ini dipopulerkan oleh seorang penulis kenamaan yang bernama Daniel Goleman dengan sebuah buku Emotional Intelligence. 
Pentingnya kecerdasan emosional dalam kehidupan seseorang telah disitir oleh Goleman (1996) yang mengatakan bahwa kecerdasan bila tidak disertai dengan pengolahan emosi yang baik tidaklah akan menghasilkan seseorang sukses dalam hidupnya. Selanjutnya ia mengatakan bahwa peranan kecerdasan akademik hanyalah sekitar 20\% untuk menopang kesuksesan hidup seseorang, sedangkan $80 \%$ lainnya ditentukan oleh faktor yang lain, yang diantaranya adalah faktor kecerdasan emosional. Pendapat lain yang senada dengan Goleman, dikemukakan oleh Patton (1998) yang mengatakan bahwa orang yang kecerdasan emosionalnya tinggi cenderung akan mengalami kesuksesan ditempat kerjanya. Patton (1998) mendefinisikan kecerdasan emosional sebagai suatu kemampuan untuk menggunakan emosi secara efektif dalam mencapai suatu tujuan.

Gardner (1993), menyebut istilah kecerdasan emosional dengan istilah kecerdasan antarpribadi dan kecerdasan intrapribadi, adapun definisi dari kedua istilah tersebut adalah sebagai berikut:

1) Kecerdasan antarpribadi adalah kemampuan untuk memahami orang lain, yang wujudnya berupa pemahaman terhadap apa yang memotivasi mereka, bagaimana mereka bekerja, dan bagaimana mereka bekerja sama dengan sesamanya. Dalam rumusan yang lain, ia mengatakan bahwa kecerdasan antar pribadi itu mencakup kemampuan untuk membedakan dan menaggapi dengan tepat suasana hati, temperamen, motivasi, dan hasrat orang lain.

2. Kecerdasan intrapribadi adalah kemampuan yang bersifat korelatif tetapi terarah ke dalam diri sendiri, yang wujudnya berupa kemampuan untuk membentuk suatu model diri sendiri yang teliti dan mengacu pada diri, serta kemampuan untuk menggunakan model tersebut sebagai alat untuk menempuh kehidupan secara efektif.

Berbeda dengan kecerdasan intelektual (IQ), kecerdasan emosional (EI) lebih banyak diperoleh dari pengalaman atau pendidikan sebagaimana dikemukakan oleh Shapiro (1997) yaitu : "Perhaps the most important distinction between IQ and EI is that EI much less genetically 
loaded, providing an opportunity for parents and educators to pick up where nature left off in determining a child's chances of success." Pernyataan ini mengisyaratkan adanya harapan dan optimisme bagi pendidik (para orang tua dan guru) untuk meningkatkan apa yang dimiliki anak agar mereka memperoleh kesempatan yang lebih besar untuk berhasil atau sukses dalam menjalani kehidupannya. Hal ini akan terwujud melalui usaha yang sungguh-sungguh dari para orang tua dan pendidik di sekolah.

Ciri-ciri dari kecerdasan emosional dikemukan oleh Goleman (1996), yang memberikan ciri-ciri sebagai berikut: kemampuan untuk memotivasi diri sendiri dan tahan dalam menghadapi frustasi, kemampuan untuk mengendalikan dorongan hati dan tidak melebihlebihkan kesenangan, kemampuan untuk mengatur suasana hati dan menjaga agar beban stres tidak melumpuhkan kemampuan berpikir, dan kemampuan untuk berempati dan berdoa.

Menurut Golhman (1997) kecerdasan emosional bisa dicirikan dengan adanya kemampuan seperti: mengatur emosi, menyejukan emosi ketika dilanda kesedihan, mengendalikan emosi ketika emosi meluapluap, mampu memusatkan perhatian, berhubungan dengan orang lain secara harmonis, mampu memenuhi tugas-tugas akademik, dan bersahabat dengan orang lain. Selanjutnya, ia membagi kecerdasan emosional pada dua bagian, yaitu:

1. Kemampuan pada orang tua yang dicirikan dengan adanya kemampuan seperti: sadar terhadap emosi anak, mampu berempati terhadap anak, mampu menyejukkan hati anak, dan mampu membimbing anak.

2. Kemampuan pada anak, yang dicirikan dengan adanya kemampuan seperti: mampu mengontrol impuls, mampu menahan kepuasan, mampu memotivasi diri, mampu memahami orang lain, mampu menguasai emosi baik ketika sedih maupun ketika senang.

Salovey (dalam Goleman, 1996) menempatkan kecerdasan pribadi dari konsep Gardner kedalam definisi tentang kecerdasan emosional, ia membagi kecerdasan emosional kedalam lima dimensi, yaitu: 
1. Mengenali emosi diri yaitu kesadaran dalam mengenali perasaan sewaktu perasaan itu terjadi.

2. Mengelola emosi, yaitu menangani perasaan agar perasaan tersebut dapat terungkap dengan tepat. Pengelolaan emosi ini terwujud dengan adanya suatu kemampuan seperti menghibur diri sendiri, melepaskan kecemasan, menghilangkan kemurungan, dan mengurangi ketersinggungan.

3. Memotivasi diri sendiri, yaitu menata emosi diri sendiri untuk mencapai suatu tujuan yang dikehendaki. Motivasi diri ini terwujud dalam suatu kemampuan untuk antusias, gairah dan daya juang yang tinggi dalam mencapai kesuksesan yang disertai dengan dorongan hati yang kuat untuk mencapai cita-cita.

4. Kemampuan berempati, yaitu suatu kemampuan untuk mengetahui bagaimana keadaan perasaan orang lain.

5. Kemampuan untuk membina hubungan, yaitu ketrampilan untuk mengelola emosi orang lain sekaligus mampu membina persahabatan dengan orang lain.

Pada penelitian ini kecerdasan emosional yang diukur menggunakan skala yang disusun penulis dengan merujuk pada teori Gardner (1993), Salovey (dalam Goleman, 1995), dan Goleman (1995), adapun aspek yang diukur dalam skala ini adalah:

a. Kemampuan yang bersifat intrapersonal yang dicirikan dengan adanya mengenal emosi diri, mengelola emosi diri, kemampuan untuk memotivasi diri sehingga bersikap optimis.

b. Kemampuan yang bersifat antarpersonal yang dicirikan dengan kemampuan berhubungan dengan orang lain dan kemampuan untuk berempati.

\section{Kecerdasan Spiritual}

Istilah spiritual berasal dari akar kata spirit yang berarti roh. Kata iniberasal dari kata latin Spiritus yang berarti bernafas. Karena itu spiritual bisa diartikan sebagai roh dan nafas karena berfungsi sebagai energi 
kehidupan yang membuat seseorang menjadi hidup. Selanjutnya, istilah spiritual berfungsi sebagai sifat dari suatu bentuk kecerdasan selain intelektual dan emosional.

Kecerdasan Spiritual berarti kemampuan manusia untuk dapat mengenal dan memahami diri sepenuhnya sebagai mahluk spiritual maupun sebagai bagian dari alam semesta. Dengan memiliki kecerdasan spiritual berarti kita memahami sepenuhnya makna dan hakikat kehidupan yang akan dituju. Menurut Zohar \& Marshal (2000) Kecerdasan spiritual diartikan sebagai kemampuan untuk menghadapi dan memecahkan persoalan makna dan nilai, sehingga kecerdasan ini berfungsi untuk menempatkan perilaku dalam konteks makna yang lebih luas dan kaya, dengan kata lain kecerdasan spiritual adalah kecerdasan yang membedakan kebermaknaan tindakan atau jalan hidup seseorang dari yang lain. Selanjutnya Covey \& Meril (1991) menjelaskan bahwa kehidupan yang bermakna bukan perkara kecepatan atau efesiensi saja, tapi merupakan perkara apa dan mengapa seseorang melakukan sesuatu.

Kecerdasan spiritual adalah kesadaran yang dengannya manusia hanya mengakuinilai-nilai yang ada, tetapi juga secara kreatif menentukan nilai-nilai baru. Ahli jiwa termashur Abraham Maslow menggunakan istilah aktualisasi diri (self-actualisation) Sebagai kebutuhan dan pencapaian tertinggi seorang manusia. Maslow menemukan bahwa, tanpa memandang suku atau asal-usul seseorang, setiap orang mengalami tahap-tahap peningkatan kebutuhan atau pencapaian dalam kehidupanya. Kebutuhan tersebut meliputi: Kebutuhan fisiologi (Physiological), Kebutuhan keamanan dan keselamatan (Safety), Kebutuhan rasa memiliki, sosial dan kasih sayang (social), Kebutuhan akan penghargaan (Esteem), Kebutuhan aktualisasi diri (Selfactualisation)

Maslow (dalam Prijaksono \& Erningpraja, 2003) mendefinisikan aktualisasi diri sebagai sebuah tahapan spiritualitas seseorang, dimana seseorang berlimpah dengan kreatifitas, intuisi, keceriaan, suka cita, kasih sayang, kedamaian, toleransi, kerendahan hati, serta memiliki tujuan hidup yang jelas, dan misi untuk membantu orang lain mencapai tahap 
kecerdasan spiritual ini. Menurut Maslow pengalaman spiritual adalah peak experience, plateau-the farthest reaches of human nature. Pengalaman spiritual adalah puncak tertinggi yang dapat dicapai oleh manusia serta merupakan peneguhan dari keberadaannya sebagai mahluk spiritual, pengalaman spiritual merupakan kebutuhan tertinggi manusia. Bahkan Maslow menyatakan bahwa pengalaman spiritual telah melewati hierarki kebutuhan manusia.

Zohar \& Marshal (2000) menyebutkan tanda-tanda dari kecerdasan spiritual yang berkembang dengan baik adalah: kemampuan bersikap fleksibel (adaptif secara spontan dan aktif), kesadaran yang tinggi, kemampuan untuk menghadapi dan memanfaatkan penderitaan, kemampuan untuk menghadapi dan melampuai rasa sakit, kualitas kehidupan yang diilhami oleh visi dan nilai-nilai, keengganan untuk menyebabkan kerugian yang tidak perlu, kecenderungan untuk melihat keterkaitan antara berbagai hal, kecenderungan untuk bertanya, dan bertanggung jawab untuk membawakan misi dan nilai pada orang lain.

Pendapat lain dikemukakan oleh Tischler \& McKeage (2002) yang menyatakan bahwa kecerdasan spiritual dicirikan dengan adanya lima kemampuan inti, yaitu: 1) Kemampuan Transendental yang ditandai dengan tercukupinya kebutuhan batin, kedamaian hati, dan ketentraman jiwa dengan merasa bahwa tuhan selalu menyertai dan membimbing hidup individu 2) Kemampuan untuk memasuki kondisi spiritual yang dicirikan pada komitmen individu untuk menjalin hubungan yang dalam dengan tuhan, kekuatan iman, serta kepasrahan individu. 3) Kemampuan menanamkan nilai-nilai religius yang ditampakkan dalam aktivitas-aktivitas individu selalu merasa dalam koridor agama. 4) Kemampuan untuk memanfaatkan nilai-nilai spiritual dalam kehidupan. 5) Kapasitas untuk berperilaku saleh yang ditunjukkan dengan sikap yang mudah memberikan maaf, mensyukuri nikmat, kesederhanaan, serta mengasihi sesama.

Pendapat lain dikemukakan oleh Emmons dan Myers (2003) yang menyatakan bahwa komponen dari kecerdasan spiritual adalah: 1) Kemampuan untuk mentransendensi; 2) Kemampuan untuk mensucikan pengalaman sehari-hari; 3) Kemampuan untuk mengalami 
kondisi-kondisi kesadaran puncak; 4) Kemampuan untuk menggunakan potensi-potensi spiritual untuk memecahkan masalah; dan 5) Kemampuan untuk terlibat dalam berbagai kebajikan.

Menurut penulis, pendapat diatas masih belum tegas dalam mencirikan kecerdasan spiritual, karena itu dengan memperhatikan teori diatas dibuat definisi lain untuk memberikan kriteria kecerdasan spiritual. Menurut penulis kecerdasan spiritual adalah suatu bentuk kecerdasan dalam memahami makna kehidupan yang dicirikan dengan adanya kemampuan yang bersifat internal dan eksternal. Ciri dari kemampuan tersebut adalah:

1. Kemampuan yang bersifat internal yaitu kemampuan yang berhubungan diri dan Allah (hablun min al-Allah), cirinya adalah kesadaran terhadap sesuatu yang transenden, adanya visi yang bersifat spiritual, dan kemampuan untuk mengambil hikmah dari penderitaan.

2. Kemampuan yang bersifat eksternal yaitu kemampuan yang berhubungan dengan sesama manusia (hablun min al-nas), cirinya adalah keengganan untuk berbuat sesuatu yang merugikan orang lain dan kecenderungan untuk mengajak pada kebaikan.

\section{Definisi Operasional}

Untuk menghindari kesalahpahaman maka dalam penelitian ini diberikan definisi operasional sebagai berikut:

1. Kecerdasan intelektual adalah suatu kemampuan mental untuk memecahkan masalah secara cepat, tepat dan efisien. Data ini diperoleh dari hasil tes IQ pada mahasiswa dengan menggunakan alat ukur SPM (Standart Progressif Matrices).

2. Kecerdasan emosional adalah suatu kemampuan untuk memahami dan mengelola emosi secara tepat. Kecerdasan ini dicirikan dengan adanya kemampuan yang bersifat ke dalam diri (intrapersonal) dan ke luar diri (antarpersonal). Data ini diperoleh dari pernyataan mahasiswa melalui skala kecerdasan emosional yang mengacu pada teori yang dikemukakan 
yang diukur dalam skala ini adalah: 1) Kemampuan yang bersifat intrapersonal yang dicirikan dengan adanya mengenal emosi diri, mengelola emosi diri, kemampuan untuk memotivasi diri sehingga bersikap optimis. 2) Kemampuan yang bersifat antarpersonal yang dicirikan dengan kemampuan berhubungan dengan orang lain dan kemampuan untuk berempati.

3. Skala kecerdasan spiritual. Alat ukur ini berupa skala psikologis sebanyak 30 item yang mampu mengungkap aspek dari kecerdasan spiritual.Skala ini disusun oleh penulis dengan merujuk pada teori yang dikemukakan oleh Marshal \& Deborah (2000) dan Tischler \& McKeage (2002). Aspek yang diukur dalam skala ini adalah: 1) Kemampuan yang bersifat internal adalah kesadaran terhadap sesuatu yang transenden, mempunyai visi yang bersifat spiritual, dan kemampuan untuk mengambil hikmah dari penderitaan.; 2) Kemampuan yang bersifat eksternal adalah kecenderungan untuk mengajak pada kebaikan dan keengganan untuk berbuat yang merugikàn orang lain.

Bentuk skala yang digunakan adalah skala pengukuran Likert, dimana sebagai dasar penentuan nilainya dikategorikan dalam sangat setuju (SS) diberi sḳor 5, setuju (S) diberi skor 4, netral (N) diberi skor 3, tidak setuju (TS) diberi skor 2, dan sangat tidak setuju (STS) diberi skor 1. Sebelum digunakan dalam penelitian, skala ini diuji cobakan terlebih dahulu pada mahasiswa Fakultas Psikologi Universitas Islam Negeri Malang.

Jumlah responden yang dijadikan uji coba berjumlah 151 orang, hal ini sesuai dengan pendapat yang dikemukakan oleh Nunanly (dalam Azwar, 2000) yang mengatakan bahwa untuk uji coba item diperlukan jumlah subjek sebanyak 5 atau 10 kali dari jumlah item, karena itu jumlah 151 orang sudah cukup untuk memenuhi kriteria di atas. Uji coba dilakukan untuk mengetahui tingkat validitas dan reliabilitas alat ukur. Kriteria item dianggap sahih ketika memenuhi koefisien korelasi diatas .2000 sedangkan reliabilitas skala dianggap andal ketika memenuhi nilai koefisien alfa (") minimal sebesar 6000 .

Dari hasil uji validitas dan reliabilitas ditemukan bahwa untuk skala kecerdasan emosional dari 30 item diperoleh 25 item valid dengan tingkat 
reliabilitas sebesar ".7516, sedangkan untuk skala kecerdasan spiritual dari 30 item diperoleh 10 item valid dengan tingkat reliabilitas sebesar ".7571. Dari hasil di atas bisa disimpulkan bahwa kedua skala dapat memenuhi persyaratan validitas dan reliabilitas.

\section{G. Hasil dan Pembahasan}

Sesuai dengan rumusan masalah yang ingin dijawab dalam penelitian ini, maka analisis data dilakukan dengan analisis varians yang bertujuan untuk mengetahui perbedaan tiga jenis kecerdasan ditinjau dari perbedaan fakultas yang dalam penelitian ini terdiri dari enam fakultas yaitu fakultas Tarbiyah, Sainteks, Syariah, Humaniora dan Bahasa, Psikologi, dan fakultas Ekonomi. Dalam pelaksanaan analisis, penulis menggunakan komputer program SPSS 10 for Window.

Dari hasil analisis ditemukan bahwa untuk variabel kecerdasan intelektual ditemukan nilai $\mathrm{F}=3.904$ dan $\mathrm{P}=0.022$, untuk variabel kecerdasan emosional ditemukan nilai $\mathrm{F}=1.396$ dan $\mathrm{P}=0.226$, dan untuk variabel kecerdasan spiritual ditemukan nilai $F=1.861$ dan $P=0.101$. Hasil diatas bisa diinterpretasikan bahwa perbedaan kecerdasan yang disebabkan karena perbedaan fakultas hanya terdapat pada variabel kecerdasan intelektual, sedangkan pada variabel emosional dan spiritual tidak terdapat perbedaan. Untuk mengetahui urutan dan perbedaan rerata kecerdasan intelektual bisa dilihat dari table dibawah ini:

Tabel 2

Lrutan Kecerdasan Intelektual Berdasarkan Perbedaan Fakultas

\begin{tabular}{|c|l|c|c|c|c|}
\hline No. & $\begin{array}{c}\text { Urutan } \\
\text { Fakultas }\end{array}$ & $\begin{array}{c}\text { Jumlah } \\
\text { subjek }\end{array}$ & $\begin{array}{c}\text { Skor } \\
\text { minimal }\end{array}$ & $\begin{array}{c}\text { Skor } \\
\text { Maksima } \\
1\end{array}$ & $\begin{array}{c}\text { Nilai } \\
\text { Mean }\end{array}$ \\
\hline 1 & Sains \& Teknologi & 57 & 15 & 57 & 44.65 \\
\hline 2 & Humaniora \& Bahasa & 59 & 12 & 56 & 41.75 \\
\hline 3 & Psikologi & 40 & 10 & 51 & 40.95 \\
\hline 4 & Syariah & 41 & 18 & 55 & 40.12 \\
\hline 5 & Ekonomi & 37 & 13 & 52 & 38.46 \\
\hline 6 & Tarbiyah & 70 & 5 & 52 & 38.37 \\
\hline
\end{tabular}


oleh Gardner (1993), Salovey (dalam Goleman, 1995) dan Goleman (1995). Adapun aspek yang diukur dalam skala ini adalah:

a. Kemampuan yang bersifat intrapersonal yang dicirikan dengan adanya mengenal emosi diri, mengelola emosi diri, kemampuan untuk memotivasi diri sehingga bersikap optimis.

b. Kemampuan yang bersifat antarpersonal yang dicirikan dengan kemampuan berhubungan dengan orang lain dan kemampuan untuk berempati.

3. Kecerdasan spiritual adalah suatu kemampuan untuk memecahkan persoalan makna dan nilai dalam kehidupan. Kecerdasan ini dicirikan dengan adanya kemampuan untuk memaknai yang hubungannya dengan dunia internal maupun eksternal. Data ini diperoleh dari pernyataan mahasiswa melalui skala kecerdasan spiritual yang mengacu pada teori yang dikemukakan oleh Zohar dan Marshal (2000), Tischler \& McKeage (2003).

\section{E. Populasi dan Sampel}

Populasi, menurut Hadi (1996) adalah semua individu yang termasuk dalam kriteria-kriteria sample yang ditentukan, sedangkan menurut Nadzir (1987), pengertian populasi yaitu kumpulan dari individu dengan kualitas serta ciri-ciri yang telah ditetapkan. Populasi dalam penelitian ini adalah semua mahasiswa Universitas Islam Negeri Malang.

Sampel menurut Arikunto (1991) adalah sebagian atau wakil dari populasi yang diteliti. Sampel dalam penelitian tidak selalu meneliti individu di dalam suatu populasi karena dalam setiap pengumpulan data, selalu akan berhadapan dengan faktor dana, tenaga, waktu yang tersedia untuk memperoleh data tersebut. Dengan keterbatasan tiga faktor tersebut, maka penelitian hanya dilakukan pada sebagian dari populasi. Selanjutñya Sudjana (1988) menyatakan bahwa yang dimaksud sample adalah sebagaian populasi yang dikenai langsung oleh penelitian.

Teknik pengambilan sampel yang digunakan dalam penelitian ini adalah' proportional random sampling yaitu memilih individu-individu yang ada dikelas-kelas perkuliahan dari tiap-tiap fakultas secara random dengan 
mempertimbangkan keseimbangan jumlah mahasiswa dari tiap fakultas. Berdasarkan pertimbagan tersebut diperoleh sampel sebanyak 304 orang. Untuk Fakultas Tarbiyah, Humaniora, dan Saintek diambil sebanyak dua kelas, sedangkan untuk Fakultas Psikologi, Ekonomi, dan Syariah diambil sebanyak satu kelas.

Tabel 1

Deskripsi Jumlah Sampel Penelitian

\begin{tabular}{|c|l|c|c|c|}
\hline \multirow{2}{*}{ NO } & \multirow{2}{*}{ FAKULTAS } & \multicolumn{3}{|c|}{ JUMLAH } \\
\cline { 3 - 5 } & & LAKI-LAKI & PEREMPUAN & TOTAL \\
\hline 1 & Tarbiyah & 28 orang & 42 orang & 70 orang \\
\hline 2 & Humaniora & 14 orang & 35 orang & 59 orang \\
\hline 3 & Sainstek & 13 orang & 35 orang & 58 orang \\
\hline 4 & Psikologi & 13 orang & 27 orang & 40 orang \\
\hline 5 & Ekonomi & 17 orang & 20 orang & 37 orang \\
\hline 6 & Syariah & 25 orang & 15 orang & 40 orang \\
\hline \multicolumn{2}{|l}{ Jumlah } & 110 orang & 194 orang & 304 orang \\
\hline
\end{tabular}

\section{F. Metode Pengumpulan Data}

Untuk mendapatkan data, alat ukur yang digunakan adalah berupa tes dan skala psikologis. Alat ukur yang digunakan dalam penelitian ini adalah sebagai berikut:

1. Tes Intelligensi (Standart Progressif Matrices). Tes ini berupa gambar dengan sebagian yang terpotong. Tugas subjek adalah mencari potongan yang cocok untuk gambar tersebut dari alternatif potongan-potongan yang sudah disediakan. Keunggulan alat tes ini pelaksanaannya bisa dilakukan secara klasikal, dan dengan alat tes ini subjek bisa dikelompokkan tingkat kecerdasannya menjadi 5 kelompok yaitu: 1) Intellectually superrior, 2) Definitelly above the average in intellectual capacity, 3) Intellectually average, 4) Definitely below average in intelletually capacity, 5) Intellectually defective.

2. Skala kecerdasan emosional. Alat ukur ini berupa skala psikologis sebanyak 30 item yang mampu mengungkap aspek-aspek kecerdasan emosional. Skala ini disusun oleh penulis dengan merujuk pada teori Gardner (1993), Salovey (dalam Goleman, 1995), dan Goleman (1995). Aspek 
Temuan yang paling menarik untuk dibahas dalam penelitian ini adalah mengenai kecerdasan intelektual karena jenis kecerdasan inilah yang menunjukkan adanya perbedaan antara tiap fakultas. Untuk mengetahui urutan tingkat kecerdasan intelektual pada tiap fakultas bisa dilihat dari histogram di bawah ini:

\section{Tabel 3}

Histogram Tingkat Kecerdasan Intelektual pada Tiap Fakultas

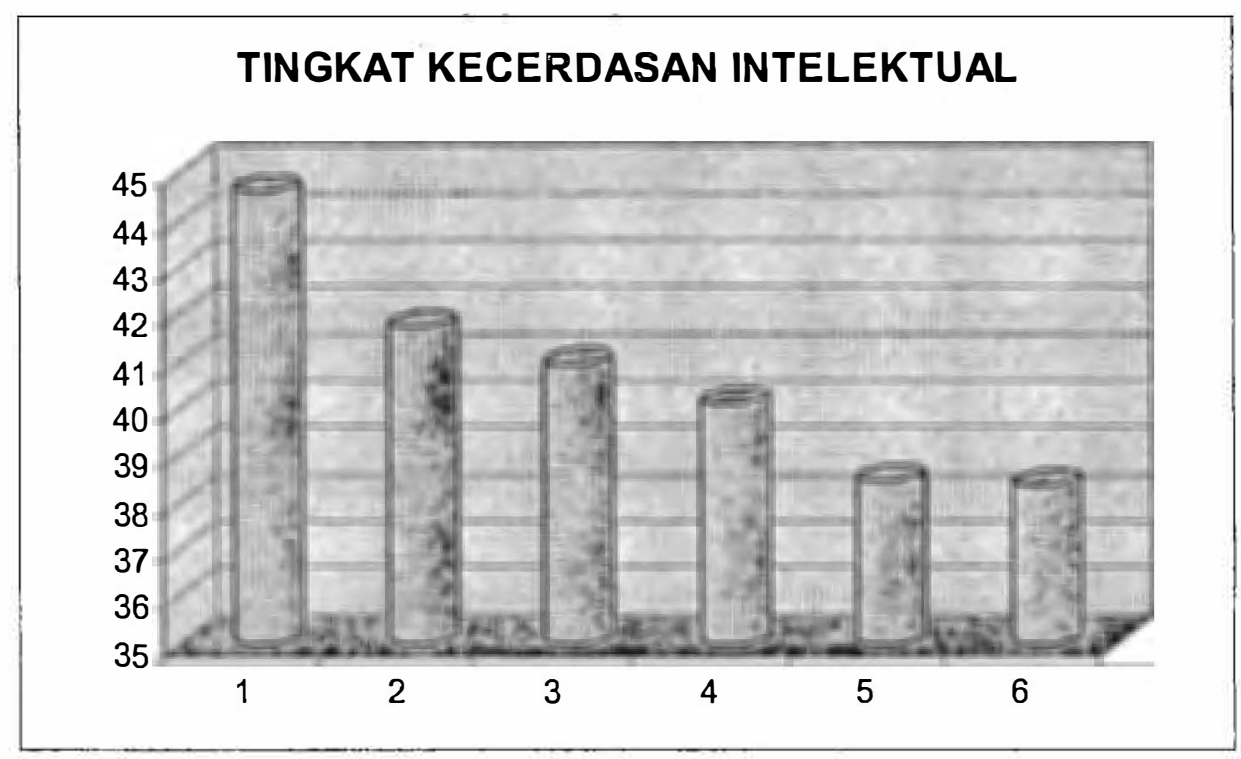

Hasil diatas tentu saja sangat menggembirakan bagi civitas akademika pada Fakultas Sains dan Teknologi, khususnya jurusan matematika yang dijadikan sebagai subjek pada penelitian ini, karena fakultas inilah yang mampu mendapatkan skor tertinggi dari kecerdasan intelektual dibanding dengan fakultas-fakultas lainnya di lingkungan UIN Malang.

Perolehan skor tertinggi kecerdasan intelektual pada fakultas Sains dan Teknologi, dimungkinkan karena mahasiswa lebih banyak mengedepankan kemampuan yang bersifat kognitif, sebagaimana tuntutan akademiknya. Misalnya para mahasiswa sering diberikan latihan dalam menghitung angka-angka yang notabene merupakan salah satu aspek penting yang diukur dalam pengukuran kecerdasan intelektual. Selain itu, mungkin saja adanya suasana akademis yang cukup kondusif di fakultas tersebut 
sehingga para mahasiswa menjadi terpacu untuk terus meningkatkan kemampuannya.

Keadaan tersebut cukup menjadikan perhatian bagi civitas akademika fakultas lainnya untuk selalu meningkatkan pelayanan para pengelola dan dosen dalam mengelola pendidikan sehingga berhasil meningkatkan kecerdasan intelektual pada mahasiswanya. Adanya perbedaan tingkat kecerdasan intelektual pada tiap-iapfakultasmenarikuntuk dikaji lebih lanjut, karena mungkin saja perbedaan ini disebabkan adanya perbedaan berbagai aspek dalam mengelola pendidikan di tiap-tiap fakultas. Data ini harus dikaji lebih lanjut sehingga ditemukan faktor yang mendasari adanya perbedaan ini, sehingga pada akhirnya setiap fakultas akan terus berusaha untuk memperbaiki hasil yang dicapai selama ini. 


\section{DAFTAR PUSTAKA}

Azwar, S., 1998. Psikologi Inteligensi, Yogyakarta: Penerbit Pustaka Pelajar

__ 2000. Pengembangan Skala Psikologis, Yogyakarta: Penerbit Pustaka Pelajar.

Arikunto, S., 1990. Manajemen Penelitian, Yogyakarta: Penerbit Rineka Cipta Aziz, R., 2001. Peranan Kecerdasan Emosional terhadap penyesuaian diri dan perilaku delinkuen pada remaja di Yogyakarta, Ulul Albab, Jumal Studi Islam, Sains, dan Teknologi, Vol. 3, No. 1.

Baron, R.A \& Byrne, D., 1997. Social Psychology, Boston: Allyn \& Bacon Cooper, R.K., \& Sawaf, A., 1998. Executive EQ, Kecerdasan Emosional Dalam Kepemimpinan Dan Organisasi, (Alih bahasa Widodo) Jakarta: Gramedia.

Efendi, A., 2005. Revolusi Kecerdasan Abad 21, Krtik MI, EI, SQ, AQ E Successful Intelligence Atas IQ, Bandung: Alfabeta.

Farid, M., \& Mashuri, 2003. Mengenal Inteligensi, Jakarta: Sains.

Hadi, S., 1996. Metodologi Research, (Jilid 3), Yogyakarta: Andi Offset.

Gardner, H., 1993. Frames of Mind, New York: Basic Book.

Ginanjar, A., 2003. Emosional Spiritual Quotient, Rahasia Sukses Membangun Kecerdasan Emosi dan Spiritual, Jakarta: Gramedia.

Goleman, D., 1995. Emotional Intelligence, Why it more than IQ, New York: Bantam Books.

Gothman, J., 1997. The Heart of Parenting: New York: Bantam Books.

Groth-Marnat, G., 1984. The Handbook of Psychological Assesment, New York: Van Nostrand Reindholt Company.

Martaniah, S.M., 1997. Model Pengembangan Sumber Daya Manusia,Jumal Psikologika, No.2, Januari.

Monks, F.j., Knoers, A.M.P., \& Haditono, S.R., Psikologi Perkembangan, Yogyakarta: Gadjah Mada University Press.

Nazir. M., 1987. Metode Penelitian, Jakarta: Ghalia Indonesia.

Patton, P., 1998. Emotional Intelligence Di Tempat Kerja, (Alih Bahasa Dahlan) Jakarta: Pustaka Delapratasa. 
Pasiak, T., 2003. Revolusi IQ, EQ, dan SQ, Antara Neurosains dan Al-Quran, Bandung: Mizan.

Raven, J.C., 1972. Guide to The Standard Progressive Matrices, (Salinan Fakultas Psikologi UGM) Yogyakarta: UGM.

Santoso, S., 2001. SPSS Versi 10, Mengolah Data Statistik Secara Profesional, Jakarta Media Komputindo.

Search, dkk, 1994. Psikologi Sosial, (terjemahan Adriyanto), Jakarta: Erlangga.

Sudjana, N., 1988. Tuntunan Penyusunan Karya Ilmiah, Bandung: Sinar Baru.

Tischler, B., \& McKeage, R., 2002. Linking emotional intelligence, spirituality and Workplace Performance, Journal of Managerial Psychology, Vol. 17, 3.

Vernon, P.E., 1973. Inteligence and Cultural Environtment, London: Methuen $\&$ Coorporation LTD.

Zohar, M., \& Marshall, I., 2000. Spiritual Intelligence, The Ultimate Intelligence, London: Blumsburry Publishing, Inc. 